\title{
Training Strategies for School Psychologists' Organizational Leadership Skills
}

\author{
Junjie Zhang \\ Teaching and Research Office, Wenling Education Bureau, Wenling, China \\ Email:6288400@qq.com
}

How to cite this paper: Zhang, J. J. (2021). Training Strategies for School Psychologists' Organizational Leadership Skills. Psychology, 12, 1711-1721.

https://doi.org/10.4236/psych.2021.1210103

Received: September 18, 2021

Accepted: October 26, 2021

Published: October 29, 2021

Copyright (c) 2021 by author(s) and Scientific Research Publishing Inc. This work is licensed under the Creative Commons Attribution International License (CC BY 4.0).

http://creativecommons.org/licenses/by/4.0/

\begin{abstract}
The mental health of schoolchildren is seen as increasingly important, and improving the organizational leadership skills of school psychologists is crucial to the development of school mental health services. This paper elaborates on some practical strategies for enhancing the five abilities inherent in organizational leadership using three training methods. The paper aims to help school psychologists to formulate appropriate development goals, maximize the optimal release of energy, and promote the development of highquality school mental health services.
\end{abstract}

\section{Keywords}

Student Mental Health, Professional Development, Leadership, Training Strategies, School Psychologists

\section{Introduction}

In recent years, Zhejiang Province, China, has invested heavily in the rapid development of mental health services in schools by expanding its teams of fulland part-time school psychologists. However, the need to improve the professional quality of these psychologists has created a bottleneck in the process. In 2001, the provincial Department of Education took the lead in setting up a mental health education and guidance center for primary and secondary schools in China. By 2017, the coverage rate of the school-level mental health education organization network in Zhejiang Province reached 91.3\% (Pang, 2018). School psychologists must maintain effective communication with school leaders, teachers, parents, and students in the course of their responsibilities to ensure their involvement in the school's mental health education activities (Augustyniak et al., 2016). School psychologists should also be able to bring their ideas to the school's other activities. Their work should continually demonstrate that they 
can effectively communicate upward, downward, and laterally, and improving their organizational leadership skills is critical (Volk et al., 2016).

\section{What Organizational Leadership Means for School Psychologists}

As China's educational reforms advance, schools have begun to emphasize teacher empowerment and strengthen their professional influence and collaborative responsibilities, building a professional learning community where teachers are encouraged to actively participate in management (Mägi \& Kikas, 2009). Teachers are beginning to play an increasingly important role in school reform, and school psychologists must also take the initiative as leaders and actors in educational reform. For their work within school organizations, they not only need to have strong professional skills but also demonstrate leadership to mobilize higher participation in school mental health education (Burns et al., 2017; Volk et al., 2016; LaChance, 2021; Lavigne, 2013).

Leadership abilities include taking responsible measures when the school environment changes. School psychologists' leadership skills exhibit professional qualities and values, along with auxiliary skills. Enhancing school psychologists' leadership promotes their transformation from technicians to organizational leaders with professional attitudes, theories, and skills. Mental health education with schools is also enhanced when school psychologists become leaders (Augustyniak et al., 2016; Burns et al., 2017; LaChance, 2021).

\section{Five Abilities Needed for Organizational Leadership}

The application of psychological assessment, consultation, and intervention within public school settings is the primary responsibility of school psychologists. The school psychologist's contribution to the team primarily revolves around assessment of behavior, personality, and educational achievement as it relates to the child's overall school functioning. This requires the school psychologist leadership needs to have five aspects of ability (Thomas, 1987). The structural models of these five capabilities are shown in Figure 1. The first is competency, which refers to the professional knowledge, skills, and ethics that are necessary for pre-job. Competency is the foundation for developing skills such as carrying out group and individual counseling activities (Huebner \& Wise, 1992). The second is the ability to research and develop mental health education, including analysis of the academic situation, research using textbooks, scientific design of activities, reflection, and review. The third is influence, which refers to the ability to drive mental health education, including the persuasion of school leaders to pay attention to mental health education, persuading schoolteachers to participate in mental health education, and leading students to actively participate in education activities. The fourth is communication, which is the ability to publicize and disseminate mental health education, including the production of multimedia articles, WeChat accounts, short videos, and writing activity plans and reports. 


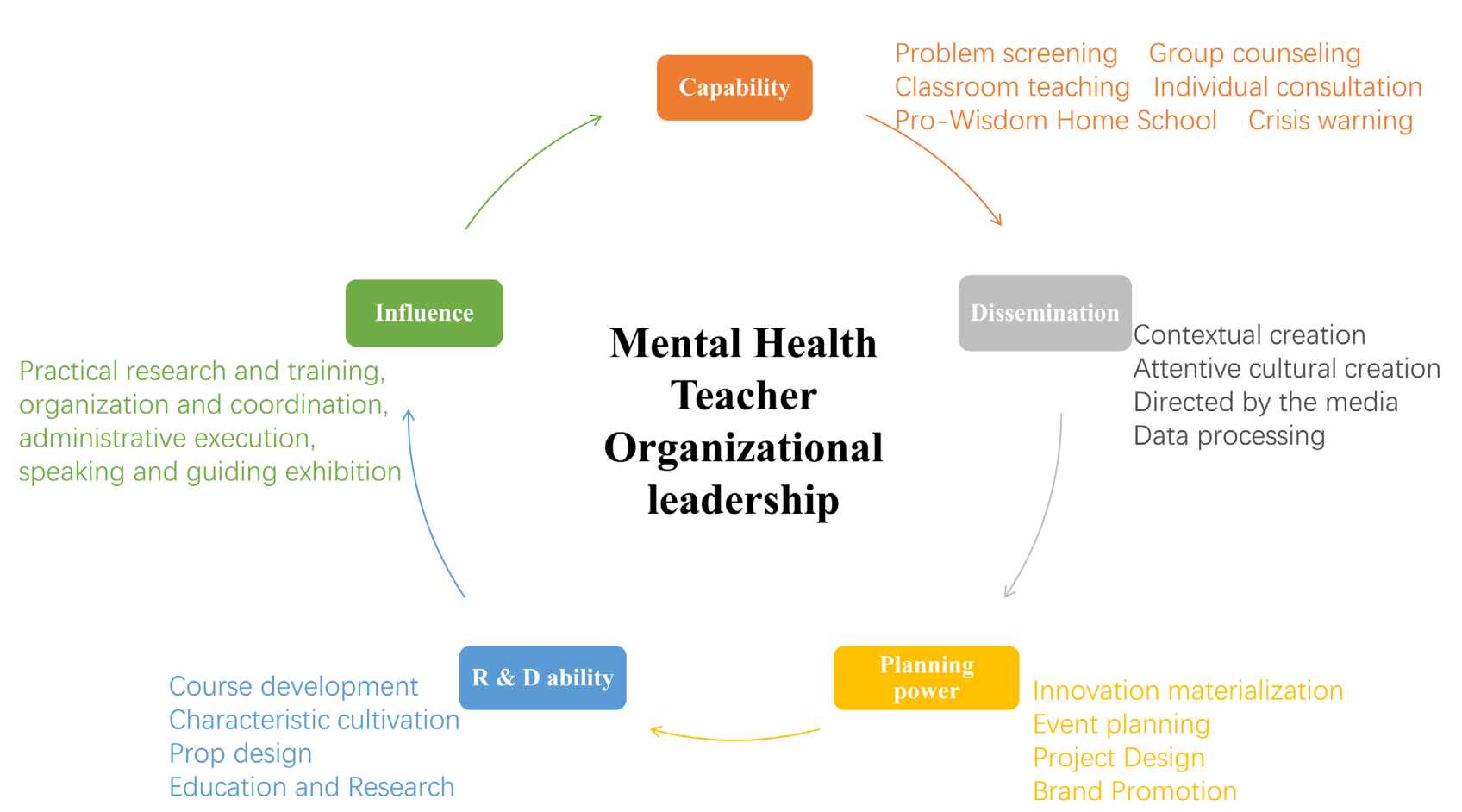

Figure 1. Structural model of school psychologists' organizational leadership.

The fifth is the ability to plan, including the organization of large-scale mental health education activities in schools, paying attention to current affairs and politics, capturing teaching problems, designing activity processes, and managing personnel (Mägi \& Kikas, 2009; Weiss, 2021; Maier et al., 2016).

\section{Curriculum Development}

To build a professional enhancement curriculum that builds leadership skills requires the cooperation of peers and management. Our research team has developed a curriculum that includes the five ability areas for organizational leadership. The curriculum covers school psychologists' work practices and integrates academic information, practical decision making, classic case studies, and other resources. We show the specific course titles and traning goals in $\mathrm{Ta}$ ble 1.

\section{Training for Organizational Leadership}

The research team used three training practices: refinement training, using media, and peer supervision to enhance the leadership skills of school psychologists.

\subsection{Refinement Training}

Refinement training aims to improve professional leadership by enhancing the communication skills of listening, respect, sincerity and empathy. Teachers learn analytical and consulting skills, define student problems, and provide real-time feedback in the form of recordings, videos, and practical exercises (Simpson \& Atkinson, 2021). 
Table 1. Course title and training goal of psychological teacher leadership.

\begin{tabular}{|c|c|c|}
\hline $\begin{array}{l}\text { Ability } \\
\text { module }\end{array}$ & Course title & Training goals \\
\hline \multirow{7}{*}{ Competence } & $\begin{array}{l}\text { Psychological Counseling } \\
\text { Skills Training }\end{array}$ & $\begin{array}{l}\text { Cultivate basic psychological counseling skills } \\
\text { for school psychologists and conduct training }\end{array}$ \\
\hline & Empathy Training & Cultivate empathy \\
\hline & $\begin{array}{l}\text { Differential Diagnosis of } \\
\text { Disease and non-disease }\end{array}$ & $\begin{array}{l}\text { Cultivate the ability to distinguish between } \\
\text { diseases and non-diseases, and understand } \\
\text { when to refer cases in a timely manner }\end{array}$ \\
\hline & $\begin{array}{l}\text { Psychological Counseling } \\
\text { Ethics }\end{array}$ & $\begin{array}{l}\text { Understand the ethics of psychological } \\
\text { counseling and strictly abide by them }\end{array}$ \\
\hline & Focus Solution Technology & $\begin{array}{l}\text { Cultivate psychological counseling skills } \\
\text { using focus-solving techniques to } \\
\text { improve their effectiveness }\end{array}$ \\
\hline & Painting Art Expression & $\begin{array}{l}\text { Cultivate psychological counseling skills } \\
\text { through painting art expression techniques }\end{array}$ \\
\hline & Sand Table Game Therapy & $\begin{array}{l}\text { Cultivate psychological counseling through } \\
\text { sand table game techniques }\end{array}$ \\
\hline \multirow{3}{*}{ Planning } & $\begin{array}{l}\text { Development and } \\
\text { Implementation of } \\
\text { Mental Games }\end{array}$ & $\begin{array}{l}\text { Cultivate the development, design, and } \\
\text { implementation capabilities of } \\
\text { psychological games }\end{array}$ \\
\hline & $\begin{array}{l}\text { Quality Development } \\
\text { Training Course }\end{array}$ & $\begin{array}{l}\text { Cultivate the leadership and implementation } \\
\text { ability of psychological games }\end{array}$ \\
\hline & $\begin{array}{l}\text { Planning and } \\
\text { Implementation of Mental } \\
\text { Health Education Activities }\end{array}$ & $\begin{array}{l}\text { Cultivate mental health education activity } \\
\text { copywriting, design, and implementation }\end{array}$ \\
\hline \multirow{3}{*}{$\begin{array}{l}\text { Communica- } \\
\text { tion }\end{array}$} & $\begin{array}{l}\text { WeChat Official Account } \\
\text { Article Writing and } \\
\text { Typesetting Design }\end{array}$ & $\begin{array}{l}\text { Cultivate WeChat, tweet, and typesetting } \\
\text { and aesthetic abilities }\end{array}$ \\
\hline & $\begin{array}{l}\text { Micro Video Shooting } \\
\text { and Production }\end{array}$ & $\begin{array}{l}\text { Cultivate use of cameras and video recorders, } \\
\text { learn to shoot micro-videos, and learn to use } \\
\text { various editing software }\end{array}$ \\
\hline & $\begin{array}{l}\text { Basic Techniques of } \\
\text { Photography }\end{array}$ & Cultivate aesthetics of photography \\
\hline \multirow{3}{*}{$\begin{array}{r}\text { Research and } \\
\text { development }\end{array}$} & $\begin{array}{l}\text { Selection and Writing } \\
\text { of Papers }\end{array}$ & Cultivate the ability to write papers \\
\hline & $\begin{array}{l}\text { Project Design and } \\
\text { Implementation }\end{array}$ & Cultivate writing ability \\
\hline & $\begin{array}{l}\text { Writing Psychological } \\
\text { Counseling Case Reports }\end{array}$ & Cultivate the ability to write up case reports \\
\hline \multirow[b]{2}{*}{ Influence } & Leadership Development & Cultivate leadership and execution ability \\
\hline & Effective Communication & $\begin{array}{l}\text { Cultivate upward, downward and } \\
\text { lateral communication abilities }\end{array}$ \\
\hline
\end{tabular}

Starting in 2015, 16 schools in X city formed 30 teams of school psychologists. The teams participate in online psychological training courses, as listed in the curriculum table. To ensure the effectiveness of training, refinement training ac- 
tivities are carried out every two weeks and conducted among random groups. The roles of observers, supervisors, visitors, and consultants are assigned within the groups. Studies indicated that instead of "passive learning," "interactive learning," such as role play training-a process in which the trainees take part in roleplays with actors in situations taken from real life experiences-has a better longterm learning impact in school settings (Shapira-Lishchinsky, 2020).

An example of what takes place in training can be seen in a typical Focus Solution Technology session where everyone takes turns playing the roles. Observers are responsible for observing and recording the entire process of consultation, recording gains and questions, and facilitating sharing after the session. Supervisors are responsible for helping the consultants deal with emotions, intervention strategies, and process support. The role of the visitor is to present a real-life problem for the consultation, while preserving the privacy of others (pseudonyms can be used). During the training process, the counselor consults the visitor and uses focus solution technology as a guide. The group members expressed that they had gained a lot, and they had better insight into their daily work.

In Artistic Expression of Painting training, one member serves as the leader, and the other members are students. Under the guidance of the leader, they learn about and experience artistic expression through painting. At the end of the session, each member shares their gains and questions, allowing growth.

\subsection{Using Media}

Short videos, micro-classes, various forms of group chats, and live broadcasts provide more possibilities for school psychologists to enhance their organizational leadership. Through short videos and micro-classes on related topics, a group chat can be set up and a live broadcast conducted in response to teachers' questions in the group chat. This distribution method can target the relevant counselors so that they have more opportunities to effectively use their fragmented time for learning and improving their skills (Frank \& Michalopoulou, 2021).

Every semester, schools carry out two or three mental health education themed activities. A school's full-time school psychologist plans activities, develops games, and publicizes the activities according to the school's needs. Every mental health activity must be recorded, including photos, videos, and activity reports. Activities can be recorded with Meipian or WeChat for instance, and these become part of the school's records. In practice, school psychologists not only learn photography and video skills but also improve their communication skills in writing the activity reports.

\subsubsection{Case Study}

City No. 3 Middle School carries out thematic mental health activities every semester. The theme of one Mental Health Month activity was Sweet October, which was inspired by the suggestion to find a mental activity that is like a delicious dessert and helps students to take a break from studying. The event organizer designed and shared the invitation in the WeChat group so that mental health 
counselors in other schools could observe it. At different points of the event, counselors from other schools came to observe and participate in the event, which was also live broadcasted (Zafeiriou \& Gulliford, 2020).

\subsubsection{COVID Pandemic Changes and Dawn of Mind}

In January 2020, the COVID-19 pandemic turned people's lives upside down. "With extended holidays, students are forced to stay home, and they can't help but feel confused. Coupled with academic pressure, life changes and tension brought about by the epidemic, psychological problems are more likely to occur." The challenge became how to maintain the mental health of students, as they were on the front lines of the pandemic war (Reupert et al., 2021). The research team used the WeChat public forum Dawn of Mind to publish Everyday Mental Health Coaching, which is the first online mental health micro-class tailored to the researchers' city, providing online support for primary and middle school students. Everyday Mental Health Coaching immediately caught the interest of many parents and teachers and had 10,000 hits within a few days.

The publicly accessible portion comprises three parts: micro-classes, coaching files, and a counseling space. At least two micro-classes are launched every other day. The micro-classes are based on the situational model in which school psychologists are invited to analyze and explain students' mental health problems using micro-film, short lectures, and other modes. As one parent messaged to the forum, "Stay calm and watch the short video that can help you understand 'unique me', and listen to the counselor's practical recommendations, which were very helpful to me."

The development of the psychological growth micro-classes is based on childhood development and incorporates the five abilities of school psychologists. The program comprises four micro-curricula that are disseminated on the Dawn of Mind WeChat public forum (see in Figure 2).

The micro-classes contain operating steps, related counseling theories, media selection, personnel task division, supplementary text materials, and task charts. In the evaluation of psychologists, the top-level concept of counseling, learning support, design of main activities, and counseling tracking for special groups are clarified. Combined with offline tutoring activities, the micro-classes are reviewed, refined, and deepened. This development model requires continuous exploration, practice, reflection, and repeated improvements to the original process to create an innovative and growing micro-course (Frank \& Michalopoulou, 2021).

The four characteristics of curriculum development. 1) Sprout. We take the age characteristics of children in lower grades into account and use flat, graphic, concrete, and audio educational media. We especially prefer audio picture books and short videos with pictures and text. Micro-classes take the scene mode as the starting point and employ Powerpoints, micro-film, micro-training, and short lectures for simple mental health presentations. 2) Fun. Parents born after 1985 like short and precise self-media learning methods. They are more willing to accept video-based check-ins instead of written materials, and they gain a great 


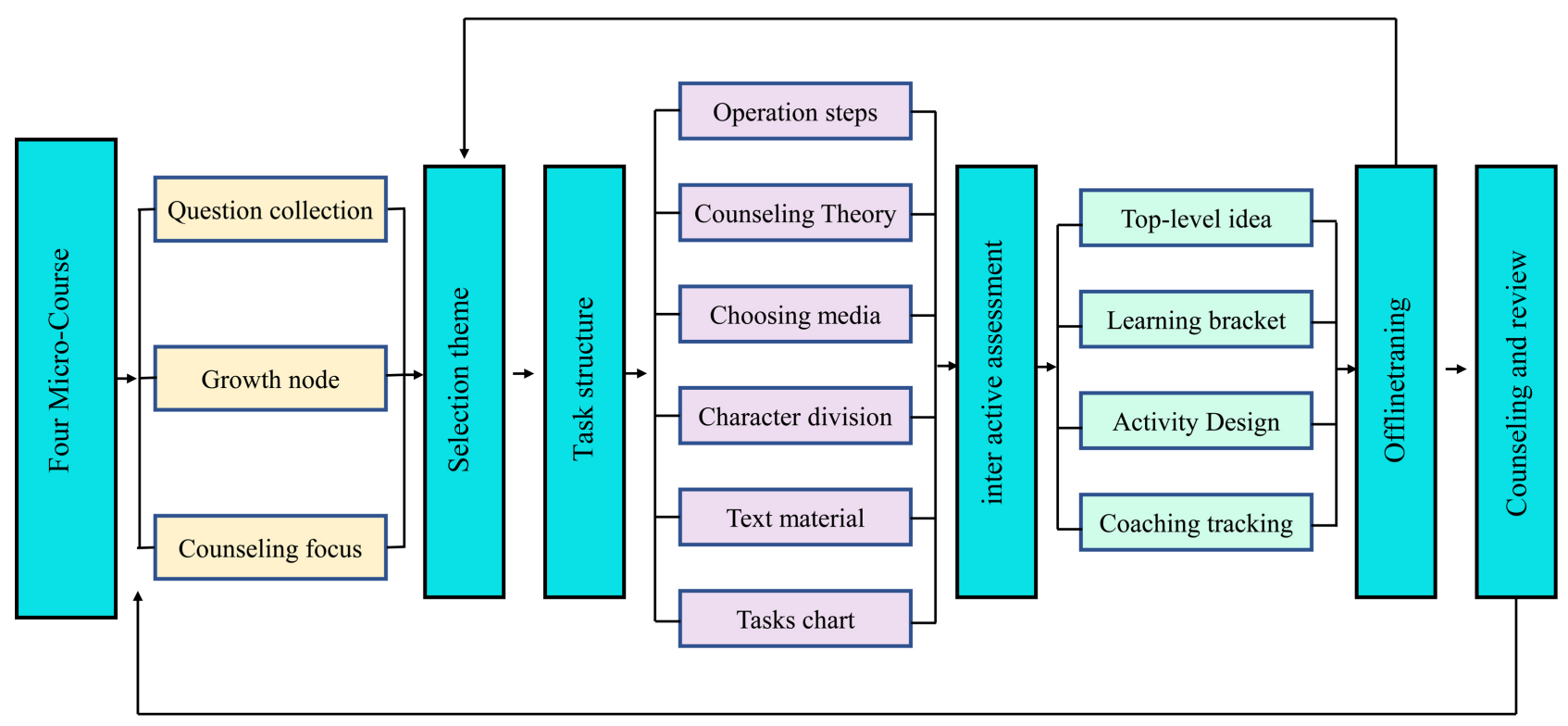

Figure 2. Development diagram of the psychological growth micro-course.

sense of accomplishment in the application of self-media. With the in-depth participation of parents, the coaching effect is more revealing. 3) Accurate. Nowadays, online micro-classes are more commonly used, and it is more usual to post materials directly to the Internet, creating a reading burden for parents. Our micro-classes refine the key points of information in each course and provide corresponding solutions and practical suggestions, which is a popular delivery method for parents. Only when there are problems, theories, and exercises, can parents and children gain something from the information. 4) Orderly. The micro-class content is scripted, and the operating steps, counseling theory, selection of media, personnel roles, text materials, and task charts are organized so that parents can carry out counseling activities smoothly and effectively. 5) Interaction. The embodied cognition theory in psychology emphasizes the body and its activities to shape cognition. Behavior determines attitudes and promotes emotions. In order to increase children's self-efficacy, a micro-class also matches peers and promotes parent-child interactions, leading to individual psychological growth and the increase of defensive effects in scientific actions.

\subsection{Peer Supervision}

The assessment process is a critical part of teacher and school leadership training programs (Nutov et al., 2021). Peer supervision is an effective and objective assessment, which comprises the supervision and evaluation of the improvement of the overall organizational leadership abilities of school psychologists and the supervision of their personal growth. From the overall perspective of supervision, we think about the construction of the supervision system, training methods, teacher needs, and learning conditions. From the perspective of personal growth, we think about the effectiveness and questions that psychologists have about personal organizational leadership improvement (Musundire, 2021). 
Whether it is sharing and observing classroom teaching seminars or observing skills and practices, in action learning, teachers exchange roles and observe each other based on trusting relationships and equal mutual assistance from their peers. With peers, they think about the cultivation of practical knowledge in the formation of various skills and use reflection and critical thinking to guide organizational leadership abilities improvement.

\section{Case Study}

The X City Heart Guidance Office organizes school psychologists to carry out peer supervision activities on a regular basis. Peer supervision adopts a circular mode in which counselor A supervises counselor C, and three counselors, D, E, and $\mathrm{F}$ act as observers of the entire process. After the supervision, all five counselors provide feedback. The supervision process is recorded, and the verbatim drafts of the dialogues are sorted into typical cases. In addition to case study and peer supervision, there are monthly group preparations on counseling topics between groups, and a review analysis after the implementation of the group counseling program to improve the effectiveness of individual and group counseling.

In the peer supervision activities of the $\mathrm{XX}$ school, all members carried out theoretical learning and experience in the Balint Group mode, organized by the author and school psychologists from other schools. First, the author explained the origin of the Balint Group and introduced the objectives and activity processes. In the initial self-introduction session, each member stated they were highly expectant about the outcomes. Immediately afterward, participants thought about cases in their own lives or work. Participants were asked to speak freely to suggest cases for discussion, which were voted on by a show of hands for discussion. Once the case was confirmed, participants asked questions about it. The case narrator then withdrew from the circle and listened without talking. The other team members relayed their feelings but did not analyze or comment on the case itself. Finally, the case narrator shared their feelings, and the observers were invited to relay their thoughts. The participants said that the peer supervision process was a great experience, and they gained a lot from it.

\section{Conclusion}

In 2005, the American School Counseling Association pointed out that school psychologists must go beyond the traditional school counseling model and clinical counseling experience (Farrell et al., 2005). It is necessary to change the consciousness of the role and shift it from its marginal position to the school's core as part of adherence to the principles of educational reform, and participation in the planning and work of a school's environmental design (Shernoff et al., 2016).

As a leader, the school psychologist must trigger educational changes in classrooms, the school, and families through the examination of their professional beliefs (Volk et al., 2016). The school psychologist must proactively contact all 
parties in the school, families, and community to strengthen mutual understanding and cooperation; establish interpersonal relationships with other teachers and parents; and design higher-level action plans that are incorporated into schools and families. Through group alliances, mentor-and-apprentice pairing, and other growth communities, the school psychologist can cultivate organizational leadership with levels, gradients, and effectiveness and strategically and wisely promote the school's mental health education work (Shernoff et al., 2016).

\section{Highlights}

- School psychologists must cultivate organizational leadership skills.

- Organizational leadership comprises five ability areas.

- Dissemination of mental health learning tools via social media platforms is effective.

- Parents and schools appreciate the leadership of school psychologists.

\section{Acknowledgements}

Thanks to the teachers and students who participated in the survey in the current study.

\section{Author Contributions}

Junjie Zhang made a significant contribution to the work reported, whether that is in the conception, study design, execution, acquisition of data, analysis and interpretation, or in all these areas; took part in drafting or critically reviewing the article; gave final approval of the version to be published; have agreed on the journal to which the article has been submitted; and agree to be accountable for all aspects of the work.

\section{Conflicts of Interest}

The author declares no competing interests.

\section{References}

Augustyniak, K., Kilanowski, L., \& Privitera, G. J. (2016). Perceptions of Leadership Practices of School Psychologists: Views of Multiple Stakeholders. School Psychology Forum, 10, 371-385.

Burns, M. K., Preast, J. L., Kilpatrick, K. D., Taylor, C. N., Young, H., Aguilar, L. et al. (2017). Leadership Theory for School Psychologists: Leading for Systems Change. Communiqué, 46, 30-31.

Farrell, P., Jimerson, S. R., Kalambouka, A., \& Benoit, J. (2005). Teachers' Perceptions of School Psychologists in Different Countries. School Psychology International, 26, 525544. https://doi.org/10.1177/0143034305060787

Frank, W. A., \& Michalopoulou, L. E. (2021). School Psychologists as Agents of Change: Implementing MTSS in a Rural School District. Psychology in the Schools, 58, 1642 1654. https://doi.org/10.1002/pits.22521

Huebner, E. S., \& Wise, P. S. (1992). Training Preservice School Psychologists to Facilitate 
the Implementation of the Regular Education Initiative in Rural Schools. Rural Special Education Quarterly, 11, 20-29. https://doi.org/10.1177/875687059201100304

LaChance, J. A. (2021). School Psychologists as Leaders in Professional Practice: An Examination of Leadership Roles and Perceived Support. Doctoral Dissertation, Chapman University.

Lavigne, P. (2013). School Psychologists, Principals, and the Leader Member Exchange Theory: Implications for the Roles and Job Functions of School Psychologists. Doctoral Dissertation, University of La Verne.

Mägi, K., \& Kikas, E. (2009). School Psychologists' Role in School: Expectations of School Principals on the Work of School Psychologists. School Psychology International, 30, 331-346. https://doi.org/10.1177/0143034309106943

Maier, M. P., Pate, J. L., Gibson, N. M., Hilgert, L., Hull, K., \& Campbell, P. C. (2016). A Quantitative Examination of School Leadership and Response to Intervention. Learning Disabilities Research \& Practice, 31, 103-112. https://doi.org/10.1111/ldrp.12100

Musundire, A. (2021). Peer Supervision: A Missing Link between Teacher Development and Quality of Teaching-Perceptions of School Managers and Classroom Teachers in South Africa. International Journal of Teacher Education and Professional Development (IJTEPD), 4, 97-115. https://doi.org/10.4018/IJTEPD.2021070107

Nutov, L., Gilad-Hai, S., \& Maskit, D. (2021). Complementary Assessment in Teacher and School Leadership Training: Necessity, Conceptualization and Validation. Studies in Educational Evaluation, 71, Article ID: 101070. https://doi.org/10.1016/j.stueduc.2021.101070

Pang, H. W. (2018). Mental Health Education in Primary and Secondary Schools in Zhejiang Province: History, Experience and Prospect. Chinese Teachers, No. 5, 24-27.

Reupert, A., Schaffer, G. E., Von Hagen, A., Allen, K.-A., Berger, E., Büttner, G., Power, E. M., Morris, Z., Paradis, P., Fisk, A. K., Summers, D., Wurf, G., \& May, F. (2021). The Practices of Psychologists Working in Schools during COVID-19: A Multi-Country Investigation. School Psychology. https://doi.org/10.1037/spq0000450

Shapira-Lishchinsky, O. (2020). Proposing a New Model for Long-Term Learning among Mid-Level School Leaders: Toward Enhancing Organizational Learning via Simulation Training. International Journal of Educational Management, 34, 1375-1386. https://doi.org/10.1108/IJEM-08-2019-0296

Shernoff, E. S., Frazier, S. L., Marínez-Lora, A. M., Lakind, D., Atkins, M. S., Jakobsons, L. et al. (2016). Expanding the Role of School Psychologists to Support Early Career Teachers: A Mixed-Method Study. School Psychology Review, 45, 226-249. https://doi.org/10.17105/SPR45-2.226-249

Simpson, J., \& Atkinson, C. (2021). The Role of School Psychologists in Therapeutic Interventions: A Systematic Literature Review. International Journal of School \& Educational Psychology, 9, 117-131. https://doi.org/10.1080/21683603.2019.1689876

Thomas, A. (1987). School Psychologist: An Integral Member of the School Health Team. Journal of School Health, 57, 465-468. https://doi.org/10.1111/j.1746-1561.1987.tb03196.x

Volk, D. T., Sanetti, L. M., \& Chafouleas, S. M. (2016). The Whole School, Whole Community, Whole Child Model: An Opportunity for School Psychologists to Show Leadership. Communiqué, 44, 1-18.

Weiss, S. (2021). Predictors of School Psychologists' Use of Exposure Interventions. Doctoral Dissertation, Rutgers The State University of New Jersey, Graduate School of Applied and Professional Psychology. 
Zafeiriou, M. E., \& Gulliford, A. (2020). A Grounded Theory of Educational Psychologists' Mental Health Casework in Schools: Connection, Direction and Reconstruction through Consultation. Educational Psychology in Practice, 36, 422-442.

https://doi.org/10.1080/02667363.2020.1818553 